\title{
is Research Square \\ Bibliometric Analysis of Research Trends And Characteristics of Drug-Induced Gingival Overgrowth
}

\author{
Ruonan Zhang \\ Huazhong University of Science and Technology \\ Jie Wu \\ Huazhong University of Science and Technology \\ Xiaoxiao Wang \\ Peking University Third Hospital \\ Jiangyuan Song ( $\nabla$ songjiangyuan12@126.com ) \\ Huazhong University of Science and Technology https://orcid.org/0000-0001-8838-3306
}

\section{Research}

Keywords: Bibliometric, Citation analysis, Research trends, Drug-induced gingival overgrowth

Posted Date: December 28th, 2021

DOI: https://doi.org/10.21203/rs.3.rs-1164878/v1

License: (c) (1) This work is licensed under a Creative Commons Attribution 4.0 International License. Read Full License 


\section{Abstract}

Objectives: Drug-induced gingival overgrowth (DIGO) is a common adverse drug reaction generally caused by the cyclosporine, phenytoin and nifedipine which belong to the category of immunosuppressant, anticonvulsant and calcium channel blocker respectively. The objective of the bibliometric analysis was to depict main citation characteristics and analyze research trend in the field of DIGO.

Methods: An exhaustive search was performed in the Scopus database for the bibliometric list of DIGO in the syntax. The information related to the number of citations, drugs related to DIGO, study topic and design, authorship, year of publication, journal, contributing institution, country of origin and department was extracted.

Results: A total of 399 papers on DIGO were retrieved. The total number of citations and that after removal of selfcitations is 7814 and 7314 , respectively. The mean number of citations is 19.6 , with a range of 0 to 608 . Article (76.9\%) and review (19.5\%) are the main paper types. A remarkable increasing trend in the number of citations is observed since 1994. Cyclosporine (45\%) is the most common used drug which has close relation with DIGO, followed by nifedipine, phenytoin (both are 18\%), amlodipine (7\%). Review (28\%) constitutes the most design in the study of DIGO. According to the top 20 keywords, the risk factors and pathogenesis of DIGO have been the hot area of research for several years.

Conclusions: The bibliometric study is the first of its kind to identify the top-cited articles and their main characteristics and research trend of DIGO. Risk factors and pathogenesis is the hotspot of research in the field of DIGO. More high level of scientific evidence on DIGO, such as systematic reviews and randomized controlled trials, are encouraged to serve as good helper to reduce the incidence and severity of DIGO.

\section{Introduction}

Drug-induced gingival overgrowth (DIGO) is a side-effect caused by the systemic medication. The most common drugs related to DIGO are cyclosporine, phenytoin and nifedipine which belong to the category of immunosuppressant, anticonvulsant and calcium channel blocker respectively. In addition, the three drugs also have the highest prevalence of DIGO as adverse drug reaction. With $50 \%$ in phenytoin [1], the prevalence rate for nifedipine is ranging between $6 \%$ and $15 \%[2,3]$. And for cyclosporine, the overall rate is $25-30 \%$ [4]. Gingival enlargement, tooth malposition [5] and long-term tooth loss are readily involved in patients with DIGO [6]. The managements of DIGO include oral hygiene instruction, professional scaling and root planning [7], surgical intervention and withdrawal or substitution of the causative drug [8]. However, the recurrence of DIGO is quite common in cases in which drug cessation or replacement are impossible [6]. Therefore, studies on this field should be pushed forward to provide novel information for the development of proper preventative and therapeutic strategies.

Bibliometric analysis is the area of citations which collects citation data to evaluate the scientific influence of a paper in its particular field [9]. Citation data (i.e., data on references cited in footnotes or bibliographies of scholarly research publications) could explain for the "impact", "influence", or "quality" of scholarly work. And the number of citations of a paper indicate the interest of researchers on using the data to perform their own studies [10]. Besides, bibliometric analysis could also help researchers to identify the trend and hotspots of the field. Thus, bibliometric analysis is a useful tool for researchers and clinicians to conduct the research and implement clinical decisions.

However, no bibliometric analysis has been published on DIGO. Therefore, we perform a bibliometric analysis on this field to investigate the research trend and hotspots of DIGO and characteristics of articles on DIGO, including the 
number of citations, study topic and design, authorship, year of publication, journal, contributing institution, country of origin and department.

\section{Materials And Methods}

The Scopus citation index was used to obtain citation information about published articles on DIGO [10]. Using the search strategy (TITLE-ABS-KEY (drug-induced gingival overgrowth) OR (drug-induced gingival hyperplasia) OR (druginduced gingival enlargement) OR (drug-induced gingival proliferation) OR (drug-induced hypertrophic gingivitis)), we searched in the Scopus database from 1971 to 6 January 2021. The language, study type, and design of the papers were not restricted. With the search strategy above, a total of 431 papers were retrieved from the SCOPUS database. All the papers were sorted in descending order according to their citation counts. In cases of papers with the same number of total citations, the papers with highest citation density were positioned higher in the ranking. The titles, abstracts or full texts of these papers were then evaluated to confirm their relevance to DIGO by two independent authors (RNZ and $\mathrm{JW}$ ). And the following information were recorded: paper type, publication title, publication year, the number of papers by year, number of citations and self-citations, citation density (mean number of citations per year = total number of citations/years since publication of the article [11]), keyword, design, area of study, author and corresponding h-index ( $h$ was defined as the number of papers with citation number $\geq h$ [12]), institution, country or region of origin, name of the journal, journal impact factor (IF), quartile (2019 Journal of Citation Reports (JCR): Science Edition), level of evidence [13-15] and department involved. In case of disagreements, the suggestion of a third author (JYS) was required to achieve consensus. This research did not require any animal or human subjects to acquire ethics committee approval.

\section{Results}

\section{Citation characteristics of the articles included}

From 1971 (year of the first publication) to 6 January 2021 (the time of the search), a total of 431 papers are retrieved from the SCOPUS database. After eliminating the non-relevant papers, 399 research articles are included for quantitative analyses. Of the 399 articles, $76.9 \%$ are original articles, $19.5 \%$ are reviews, $3.6 \%$ are other types of articles (book chapter $1.0 \%$, short survey $1.0 \%$, conference paper $0.5 \%$, letter $0.5 \%$ and note $0.5 \%$ ) (Fig. $1 \mathrm{a}$ ).

Citation characteristics are summarized based on 333 papers which have citations data available. The total number of citations and that after removal of self-citations is 7814 and 7314, respectively. The number of citations of these papers ranges between 0 and 608 with a mean of 19.6 citations per paper. A remarkable increasing trend in the number of citations is observed since 1994 (Fig. 1b). The highly cited article with 608 citations is that of Mayer et al published in the Transplantation in 1997, followed by the articles published by Faulds et al in 1993 (462 citations), Seymour et al in 1996 (272 citations) and Hassell et al (209 citations) in 1991. As for the citation density, the most cited article also has the highest citation density (25.3). The top 2 articles are cited more than 400 times; with 13 highest ranked articles in the list receives more than one-third of the total citations. The overall $h$ index and $h$ index after removal of self-citations is 46 and 44 , respectively. The general information on the ranking, first author, title, year and journal of publication, number of citations, citation density, and type of the 20 top-cited papers on DIGO is shown in Table 1. The number of papers on DIGO by year of publication is shown in Fig. 1c.

\section{Topic, design, and area of study of the papers included}

The frequency of keywords in each included paper are collected and analyzed to identify the research trend and hotspots of DIGO including study topic, design and area of the study of essays about DIGO. For the commonly used 
drug, cyclosporine (45\%) is the most one which has close relation with DIGO (Fig. 2a), followed by nifedipine, phenytoin (both are 18\%), and amlodipine (7\%). For the study design, review (28\%) constitutes the most design in the study of DIGO (Fig. 2b), followed by basic research (24\%), case-report (17\%), cross-sectional study (14\%), cohort study (8\%), case-control study (4\%) and randomized controlled trial (RCT, 3\%). After removing and combining some relevant keywords, age $(n=207)$, dental plaque $(n=79)$, mouth hygiene $(n=76)$ and periodontal disease $(n=68)$ are the most common keywords which may contribute to the occurrence of DIGO. According to the top 20 keywords (Fig. 2c), calcium channel blockers $(n=185)$, chemically induced disorder $(n=126)$, immunosuppressive agent $(n=113)$, anticonvulsive agent $(n=101)$ and antihypertensive agent $(n=32)$ may be classified as the category of drugs which related to gingival overgrowth. In addition, the specific research topic such as fibroblast $(n=116)$, pathology $(n=76)$, genetics $(n=48)$ and metabolism $(n=43)$ are also showed in the list.

\section{Author, institution, country or region of origin and journal of publication and department}

The author, institution, country of origin and journal of publication and department within a specific research topic are often analyzed in the bibliometric. The most productive authors are "Seymour R.A." with 17 published articles, followed by "Thomason, J.M." with 12 published articles, who are also the only two authors that contribute over 10 papers (Fig. 3a). The majority of all authors included in our review published two papers (102 authors). In terms of the first author, Seymour R.A. also tops the list with 7 published articles, and followed by Subramani, T. with 6 published articles. The authors with the highest indices are "Page, R.C." with an h-index of 55, a total citation of 14530 and total citation per article of 56.53, followed by "Bartold, P.M." with an h-index of 55, a total citation of 13489 and total citation per article of 38.43 , and "Chapple, I.L.C." with an h-index of 50, a total citation of 8365 and total citation per article of 40.80 .

There is a total of 159 institutions, 47 of which published 3 or more papers. University of Newcastle contributes the largest number of papers ( $n=27)$, followed by Sri Ramachandra Institute of Higher Education and Research $(n=14)$ and University of São Paulo ( $n=9$ ) (Fig. 3b). About a quarter (25.2\%) of these institutions are in India. The United States and Japan rank second and third after India in the number of institutions. The contributing country with the largest number of papers is United States $(n=71)$, followed by India $(n=61)$, United Kingdom $(n=39)$ and Japan $(n=33)$ (Fig. 3c). More than half of the articles are published in the 4 highest contributing countries.

The papers are published in 175 journals, 83 of which are $\mathrm{SCl}$ journals where nearly half of the papers $(\mathrm{n}=199)$ are published. Journal of Periodontology $(n=43)$ tops the list of journals of publication number, followed by Journal of Clinical Periodontology $(n=14)$, Journal of Periodontal Research $(n=12)$, Archives of Oral Biology $(n=11)$ and Journal of Indian Society of Periodontology ( $n=10)$ (Fig. 3d). For the 2019 journal IF (Impact Factor), Annals of Internal Medicine $(\mathrm{IF}=21.317)$ and Journal of The American Academy of Dermatology (IF=8.277) are two journals with highest IF. However, when it comes to the SCI journals in the field of stomatology, the one with highest IF is Periodontology 2000 (IF=7.718) (Fig. 3e). Journal rankings in each subject category are divided into quartiles by the SCImago Journal Rank. There are four quartiles: Q1 to Q4, which rank the journals from highest to lowest, educed from their impact index [11]. According to 2019 JCR, 26 journals are divided into Q1, 21 into Q2, 14 into Q3, 22 into Q4.

The departments involved are evaluated per article. Dentistry published the most articles $(n=307)$, followed by pharmacy $(n=55)$, basic medicine $(n=29)$, Nephrology $(n=24)$, and organ transplantation department $(n=22)($ Fig. 4a). The collaborative studies are also observed as defined by the number of cooperation departments per article and the situation of collaborations with dentistry. It is demonstrated that there are six departments to cooperate at most and 244 papers are completed by a single department (Fig. 4b). The department that collaborates most with the dentistry is pharmacy $(n=29)$, followed by basic medicine $(n=24)$, Nephrology $(n=15)$, histopathology $(n=13)$ and Laboratory $(n=10)$ (Fig. 4c). 


\section{Discussion}

The bibliometric study presents one of the first efforts to identify the top-cited articles and their main characteristics and research trend in the field of DIGO. Seymour et al., are the most productive authors in the field of DIGO, and Page, R.C. et al., are the authors with highest indices. University of Newcastle is the most productive institution and India has the most publishing institutions. The risk factors and pathogenesis of DIGO are the two main hotspots in the field of DIGO. We also evaluate the relevant journals from the citation numbers, IF and quartiles. Our bibliometric analyses can help to provide insight into the status of research within DIGO, identify strengths and limitations, and highlight articles that can assist researchers, trainees, and clinicians.

Although the articles of DIGO is relatively scant (only 399 articles), there is no lack of classical works. Generally speaking, an article cited more than 400 times should be considered a classic; but in some fields with fewer researchers, 100 citations might qualify a work [12]. Among the top 20 most cited articles (Table 1), the top two papers have been cited more than 400 times, followed by 11 articles with over 100 citations. The top 20 cited articles were published from 1976 to 2004, including 12 reviews and 8 articles. Over half of the articles $(n=13)$ emphasized the pathogenesis of DIGO, and these articles also highlighted that the mechanism of DIGO needed to understand fully. The common risk factors involved in the papers consist of age, sex, drug variables, periodontal variables and genetic factors. The basic researches aimed at the mechanism of DIGO mentioned in the top 20 cited articles mainly focus on the cellular function and cell subpopulation heterogeneity of fibroblasts.

Only a minority of the papers (RCT 3\%) have a high evidence level according to the evidence pyramid made by various libraries [13-15] and there is no systematic review or meta-analysis. The majority of the papers in the field of DIGO have a low evidence level (i.e., review, basic research, case report). This phenomenon might imply a scarcity of highlevel evidence in DIGO and suggest us to conduct more RCTs. Although such studies may require multicenter collaborations, a lot of personnel, large funding, and patients' consent to receiving either an experimental intervention or no intervention [16]. Based on these high quality RCTs, we might have a high-quality of systematic review to guide clinicians, dentists and patients on how to use the drugs to avoid or alleviate the gingival overgrowth (GO) as far as possible. The advisable RCTs should include information such as the specific medication, the intervention (either withdraw the medication and/or professional dental cleaning and scaling), the case selection, the outcome and so forth, to establish a standard treatment protocol of DIGO and to set up an algorithm to identify the suspect DIGO patients before taking the causal drugs.

The research trend and hotspots of DIGO were ascertained by analysis of the keywords and the contents of papers included. Unsurprisingly, the top three frequency drugs related with DIGO are cyclosporine (45\%), phenytoin (18\%) and nifedipine (18\%). However, it's noteworthy that amlodipine (7\%), tacrolimus (4\%), diltiazem (4\%) and verapamil (4\%) are also related with DIGO. So, amlodipine might not always be an appropriate substitute for nifedipine in patients with DIGO. The risk factors and pathogenesis are the two main hotspots of DIGO (Fig. 2c). Risk factors involved with DIGO are age factors, medication (calcium channel blockers, immunosuppressive agents, anticonvulsant agent and so on), periodontal variables (dental plaque, mouth hygiene, periodontal disease, inflammation) and genetics [17], all are also top 20 frequency keywords in this review. As risk factors are associated with both prevalence and severity of DIGO, clinicians and dentists should be aware of these to help patients to avoid this side effects and to develop the optimal management strategies. The pathogenesis of DIGO is complicated, obscure and has been a hot area of research for several years. Fibroblast plays an important role in the pathogenesis of DIGO. Since only a subset of patients taken with these systemic medications may develop GO, researches hypothesize that these individuals have fibroblasts with an abnormal susceptibility to the drug [8]. Besides, the existence of differential proportions of fibroblast subsets in each individual exhibit susceptibility or resistance to pharmacologically induced gingival enlargement $[18,19]$. This 
view was further demonstrated that cyclosporine $A(C s A)$ could react with a phenotypically distinct subpopulation of gingival fibroblasts to enhance protein synthesis[20,21]. In addition to the role of fibroblast, other factors may contribute to the pathogenesis of DIGO (i.e., inflammatory cytokines, matrix metalloproteinase) [22].

Seymour, who devotes himself to researches on dentistry and medicine, publishes most articles related to DIGO containing the related drugs, mechanisms and management. Followed by Thomason publishes 12 articles about DIGO, all of which were completed in cooperation with Seymour. And among the top 20 cited articles, Seymour contributed three articles. All the three articles are reviews, the first one is about the pathogenesis of DIGO, the second one is about the risk factors of DIGO, and the last one is about the drugs and the periodontium. All these topics are the hot issue of DIGO, so it's no wonder that the articles of Seymour gained large number of citations in the field of DIGO.

The United States has contributed the most articles. The top-ranking position of the US is not unique to DIGO research and visible in many other fields [23-27]. This indicates that countries with greater economic background have tendency to towards biomedical research, perhaps because of better medical and scientific resources and funding [28]. The number of papers on DIGO published in the past two decades accounted for nearly two-thirds of the total. Interestingly, among them, India, surpassing the United States, has becoming the country with the largest number of publications in the past two decades. Moreover, India is the predominant country as for the number of institutions. However, most of the papers published in India in the past two decades are in vitro experiments and case reports, and the level of evidence is low. It was estimated that the incidence of periodontal disease in India is similar to that in the United States [29]. These may indicate that India, as a developing country, attaches great importance to periodontal disease research and has made a certain achievement.

The fact that 175 journals are not all in the dental field reflects the increasingly multidisciplinary researches of DIGO and the need to maximize the impact of relevant research. Journal of Periodontology and Journal of Clinical Periodontology are the top two on the list of journals of publication number. Unexpectedly, the majority of the top-cited articles are published in the Journal of Periodontology (IF=3.742) and Journal of Clinical Periodontology (IF=5.241), both of which are considered as the leading journals related to all aspects of research and clinical practice in Periodontology. This indicates that the investigators often select the two journals most frequently for publishing and obtaining information on DIGO. In general, researchers tend to publish their articles and collect related information on the reference of IF and quartile. Most of highly cited articles and high-IF journals right come from the North America or Europe. The trend of bibliometric analysis is in accordance with the Bradford's law, which suggests that authors tend to publish their papers in core journals in their respective fields, and rarely publish their work outside core journals. When authors did not choose to publish their work in core journals, the number of citations for their articles decreased [30].

When we take a look at the involvement of the departments in DIGO, the truth is that the majority of the number of cooperation is converged on dentistry alone. Pharmacy and basic medicine are the two prominent departments collaborated with dentistry. As we all known, the most common drugs related to DIGO are cyclosporine, phenytoin and Nifedipine which exactly correspond with three (organ transplantation, neurology and cardiology) of top-11 departments that have published the most relevant articles (Fig. 4c). Therefore, the condition of collaboration with dentistry fit in the trend of research fields, and there is still a lot of space for multidisciplinary team cooperation in the research of DIGO on how to avoid or relieve the prevalence or severity of GO, such as to determine the timing between medication and periodontal treatment and the time interval of periodontal treatment.

In this review, there still has several limitations in the bibliometric analysis on DIGO. First, we used only Scopus database as a reference to determine the number of citations of the articles. It has been suggested that searching in more than one database may provide a more comprehensive view of the citations because the number of citations of 
the same article may differ across the databases (i.e., Google Scholar and Web of Science) [31]. However, Scopus database could automatically exclude self-citing and provide about $20 \%$ more coverage than Web of Science, whereas Google Scholar provides results of inconsistent accuracy [32]. Second, an inherent limitation of citation analysis is the lack of correction for self-citations or the potential bias because of authors citing papers from journals in which they hope to publish their own work[33]. Third, citation analyzers tend to cite previous highly cited papers which has a time accumulation, causing potential bias. Thus, we used the citation density index to control for this potential bias, which was strongly correlated with the absolute number of citations. Fourth, citation count does not directly reflect the quality of a paper. In our study, the majority of papers provide the lowest level of evidence (i.e., review, case report).

\section{Conclusions}

This is the first article to report the bibliometric characteristics and research trend in terms of evidence-based dentistry regarding DIGO. Despite its limitations, our bibliometric analysis will facilitate the understanding of researchers and clinicians, especially those who are at the beginning of their careers in periodontology on DIGO. More high level of scientific evidence on DIGO, such as systematic reviews and randomized controlled trials, are encouraged to serve as good helper to reduce the incidence and severity of DIGO.

\section{Abbreviations}

DIGO: Drug-induced gingival overgrowth; IF: Impact factor; JCR: Journal of citation reports; RCT: Randomized controlled trial; GO: Gingival overgrowth; CsA: Cyclosporine A

\section{Declarations}

\section{Ethics approval and consent to participate}

Not applicable.

\section{Consent for publication}

Not applicable.

\section{Availability of data and materials}

Not applicable.

\section{Competing interests}

The authors declare that they have no competing interests.

\section{Funding}

This work was supported by the National Natural Science Foundation of China (82101264).

\section{Authors' contributions}

JYS contributed to conception and design of the study. RNZ and JW carried out the literature search and performed data analysis. RNZ and JW contributed to the interpretation of data and prepared the main part of the manuscript. JYS and XXW contributed to revising and supervising of the manuscript. All authors approved the final version of the 
manuscript and accept accountabilities for all aspects of the work, declaring that questions related to the accuracy or integrity of all parts of the work have been appropriately investigated and reported.

\section{Acknowledgements}

Not applicable.

\section{References}

1. Casetta I, Granieri E, Desiderá M, Monetti VC, Tola MR, Paolino E, et al. Phenytoin-induced gingival overgrowth: a community-based cross-sectional study in Ferrara, Italy. Neuroepidemiology. 1997;16(6):296-303. https://doi.org/10.1159/000109700.

2. Fattore L, Stablein M, Bredfeldt G, Semla T, Moran M, Doherty-Greenberg JM. Gingival hyperplasia: a side effect of nifedipine and diltiazem. Spec Care Dentist. 1991;11(3):107-9. https://doi.org/10.1111/j.17544505.1991.tb00828.x.

3. Ellis JS, Seymour RA, Steele JG, Robertson P, Butler TJ, Thomason JM. Prevalence of gingival overgrowth induced by calcium channel blockers: a community-based study. J Periodontol. 1999;70(1):63-7. https://doi.org/10.1902/jop.1999.70.1.63.

4. Boltchi FE, Rees TD, lacopino AM. Cyclosporine A-induced gingival overgrowth: a comprehensive review. Quintessence Int. 1999;30(11):775-83.

5. Quenel L, Keribin P, Giran G, Tessier MH, Lesclous P. Amlodipine-induced gingival enlar-gement: a case report. J Stomatol Oral Maxillofac Surg. 2020;121(3):308-11. https://doi.org/10.1016/j.jormas.2019.04.014.

6. Fardal $\varnothing$, Lygre $\mathrm{H}$. Management of periodontal disease in patients using calcium channel blockers - gingival overgrowth, prescribed medications, treatment responses and added treatment costs. J Clin Periodontol. 2015;42(7):640-6. https://doi.org/10.1111/jcpe.12426.

7. Somacarrera ML, Lucas M, Scully C, Barrios C. Effectiveness of periodontal treatments on cyclosporine-induced gingival overgrowth in transplant patients. Br Dent J. 1997;183(3):89-94. https://doi.org/10.1038/sj.bdj.4809430.

8. Trackman PC, Kantarci A. Molecular and clinical aspects of drug-induced gingival overgrowth. J Dent Res. 2015;94(4):540-6. https://doi.org/10.1177/0022034515571265.

9. Moed HF. New developments in the use of citation analysis in research evaluation. Arch Immunol Ther Exp (Warsz). 2009;57(1):13-8. https://doi.org/10.1007/s00005-009-0001-5.

10. Liu W, Wu L, Zhang Y, Shi L, Yang X. Bibliometric analysis of research trends and cha-racteristics of oral potentially malignant disorders. Clin Oral Investig. 2020;24(1):447-54. https://doi.org/10.1007/s00784-019-02959-0.

11. Gondivkar SM, Sarode SC, Gadbail AR, Gondivkar RS, Chole R, Sarode GS. Bibliometric analysis of 100 most cited articles on oral submucous fibrosis. J Oral Pathol Med. 2018;47(8):781-7. https://doi.org/10.1111/jop.12742.

12. Hirsch JE. An index to quantify an individual's scientific research output. Proc Natl Acad Sci U S A. 2005;102(46):16569-72. https:// doi.org/10.1073/pnas.0507655102.

13. Melnyk BM, Fineout E. Evidence-based practice in nursing \& healthcare: a guide to best practice. Quality Management in Healthcare 13; 2006.

14. Giuffrida MA. Practical application of evidence-based practice. Vet Clin North Am Exot Anim Pract. 2017;20(3):737-48. https://doi.org/10.1016/j.cvex.2017.04.001.

15. Forrest JL, Miller SA. Evidence-based decision making in action: part 2-evaluating and applying the clinical evidence. J Contemp Dent Pract. 2003;4(1):42-52. 
16. De la Garza-Ramos R, Benvenutti-Regato M, Caro-Osorio E. The 100 most-cited articles in spinal oncology. J Neurosurg Spine. 2016;24(5):810-23. https:// doi.org/10.3171/2015.8.SPINE15674.

17. Seymour RA, Ellis JS, Thomason JM. Risk factors for drug-induced gingival overgrowth. J Clin Periodontol. 2000;27(4):217-23. https://doi.org/10.1034/j.1600-051x.2000.027004217.x.

18. Hassell TM, Page RC, Narayanan AS, Cooper CG. Diphenylhydantoin (dilantin) gingival hyperplasia: drug-induced abnormality of connective tissue. Proc Natl Acad Sci U S A. 1976;73(8):2909-12. https://doi.org/10.1073/pnas.73.8.2909.

19. Morton RS, Dongari-Bagtzoglou Al. Regulation of gingival fibroblast interleukin- 6 secretion by cyclosporine A. J Periodontol. 1999;70(12):1464-71. https://doi.org/10.1902/jop.1999.70.12.1464.

20. Hassell T, Buchanan J, Cuchens M, Douglas R. Fluorescence activated vital cell sorting of human fibroblast subpopulations that bind cyclosporin A. J Dent Res. 1988;67(1_suppl):273. doi:10.1177/0022034588067S101.

21. Mariotti A, Hassell T, Jacobs D, Manning CJ, Hefti AF. Cyclosporin A and hydroxycyclosporine (M-17) affect the secretory phenotype of human gingival fibroblasts. J Oral Pathol Med, 1998;27(6):260-6. https://doi.org/10.1111/j.1600-0714.1998.tb01953.x.

22. Hassell TM, Hefti AF. Drug-induced gingival overgrowth: old problem, new problem. Crit Rev Oral Biol Med. 1991;2(1):103-37. https://doi.org/10.1177/10454411910020010201.

23. Ma L, Gao X, Liu W. Bibliometric analysis of the top-100 cited articles on oral potentiall-y malignant disorders to guide research topic and direction. J Dent Sci. 2020;15(4):479-85. https://doi.org/10.1016/j.jds.2019.09.011.

24. Liu W, Zhang Y, Wu L, Yang X, Shi L. Characteristics and trends of oral leukoplakia research: a bibliometric study of the 100 most cited articles. Medicine (Baltimore). 2019;98(27):e16293.

https://doi.org/10.1097/MD.0000000000016293.

25. Liu W, Ma L, Song C, Li C, Shen Z, Shi L. Research trends and characteristics of oral lichen planus: a bibliometric study of the top-100 cited articles. Medicine (Baltimore). 2020;99:e18578. https://doi.org/10.1097/MD.0000000000018578.

26. Moura LKB, Mobin M, Matos FTC, Monte TL, Lago EC, Falcão CAM, et al. Bibliometric analysis on the risks of oral cancer for people living with HIV/AIDS. Iran J Public Health. 2017;46(11):1583-5.

27. Tarazona B, Vidal-Infer A, Alonso-Arroyo A. Bibliometric analysis of the scientific produc-tion in implantology (2009-2013). Clin Oral Implants Res. 2017;28(7):864-70. https://doi.org/10.1111/clr.12891.

28. Ebrahim NA, Salehi H. Effect of number of versions on receiving high citations. TechRxiv. 2020; https://doi.org/10.36227/techrxiv.12561818.v1.

29. Janakiram C, Mehta A, Venkitachalam R. Prevalence of periodontal disease among adults in India: a systematic review and meta-analysis. J Oral Biol Craniofac Res. 2020;10(4):800-6.

https://doi.org/10.1016/j.jobcr.2020.10.016.

30. Brookes BC. Bradford's law and the bibliography of science. Nature. 1969;224:953-6. https://doi.org/10.1038/224953a0.

31. Bakkalbasi N, Bauer K, Glover J, Wang L. Three options for citation tracking: Google Scholar, Scopus and Web of Science. Biomed Digit Libr. 2006;3:7. https://doi.org/10.1186/1742-5581-3-7.

32. Falagas ME, Pitsouni El, Malietzis GA, Pappas G. Comparison of PubMed, Scopus, Web of Science, and Google Scholar: strengths and weaknesses. FASEB J. 2008;22(2):338-42. https://doi.org/10.1096/fj.07-9492LSF.

33. Rigby M. Citation analysis in health care sciences. Innovative investigation or seductive pseudo-science? Methods Inf Med. 2014;53(6):459-63. https://doi.org/10.3414/ME14-05-0004. 


\section{Tables}

Table 1 top-20 most cited papers on DIGO

Page 10/13 


\begin{tabular}{|c|c|c|c|c|c|c|c|}
\hline Rank & First author & Title & $\begin{array}{l}\text { Year of } \\
\text { publication }\end{array}$ & $\begin{array}{l}\text { Journal } \\
\text { (abbreviated name) }\end{array}$ & Type & citations & $\begin{array}{l}\text { citation } \\
\text { density }\end{array}$ \\
\hline 1 & $\begin{array}{l}\text { Mayer A.D., } \\
\text { et al. }\end{array}$ & $\begin{array}{l}\text { Multicenter } \\
\text { randomized trial } \\
\text { comparing } \\
\text { tacrolimus } \\
\text { (FK506) and } \\
\text { cyclosporine in the } \\
\text { prevention of renal } \\
\text { allograft rejection: } \\
\text { A report of the } \\
\text { European } \\
\text { tacrolimus } \\
\text { multicenter renal } \\
\text { study group }\end{array}$ & 1997 & TRANSPLANTATION & Article & 608 & 25.33 \\
\hline 2 & $\begin{array}{l}\text { Faulds D., } \\
\text { et al. }\end{array}$ & $\begin{array}{l}\text { Cyclosporin: A } \\
\text { Review of its } \\
\text { Pharmacodynamic } \\
\text { and } \\
\text { Pharmacokinetic } \\
\text { Properties, and } \\
\text { Therapeutic Use in } \\
\text { Immunoregulatory } \\
\text { Disorders }\end{array}$ & 1993 & Drugs & Review & 463 & 19.25 \\
\hline 3 & $\begin{array}{l}\text { Seymour } \\
\text { R.A. }\end{array}$ & $\begin{array}{l}\text { The pathogenesis } \\
\text { of drug-induced } \\
\text { gingival } \\
\text { overgrowth }\end{array}$ & 1996 & J. Clin. Periodontol. & Review & 272 & 11.33 \\
\hline 4 & $\begin{array}{l}\text { Hassell } \\
\text { T.M., et al. }\end{array}$ & $\begin{array}{l}\text { Drug-induced } \\
\text { gingival } \\
\text { overgrowth: Old } \\
\text { problem, new } \\
\text { problem }\end{array}$ & 1991 & $\begin{array}{l}\text { CRIT. REV. ORAL } \\
\text { BIOL. MED. }\end{array}$ & Review & 209 & 8.71 \\
\hline 5 & $\begin{array}{l}\text { Seymour } \\
\text { R.A., et al. }\end{array}$ & $\begin{array}{l}\text { Risk factors for } \\
\text { drug-induced } \\
\text { gingival } \\
\text { overgrowth }\end{array}$ & 2000 & J. Clin. Periodontol. & Review & 188 & 7.83 \\
\hline 6 & $\begin{array}{l}\text { Hassell } \\
\text { T.M., et al. }\end{array}$ & $\begin{array}{l}\text { Diphenylhydantoin } \\
\text { (dilantin) gingival } \\
\text { hyperplasia: drug } \\
\text { induced } \\
\text { abnormality of } \\
\text { connective tissue }\end{array}$ & 1976 & $\begin{array}{l}\text { PROC. NATL. ACAD. } \\
\text { SCI. U. S. A. }\end{array}$ & Article & 151 & 6.29 \\
\hline 7 & $\begin{array}{l}\text { Herranz } \\
\text { J.L., et al. }\end{array}$ & $\begin{array}{l}\text { Clinical Side } \\
\text { Effects of } \\
\text { Phenobarbital, } \\
\text { Primidone, } \\
\text { Phenytoin, } \\
\text { Carbamazepine, } \\
\text { and Valproate } \\
\text { During } \\
\text { Monotherapy in } \\
\text { Children }\end{array}$ & 1988 & Epilepsia & Article & 125 & 5.21 \\
\hline 8 & $\begin{array}{l}\text { Ilhan Uzel } \\
\text { M., et al. }\end{array}$ & $\begin{array}{l}\text { Connective Tissue } \\
\text { Growth Factor in } \\
\text { Drug-Induced } \\
\text { Gingival } \\
\text { Overgrowth }\end{array}$ & 2001 & J. Periodontol. & Article & 120 & 5 \\
\hline
\end{tabular}




\begin{tabular}{|c|c|c|c|c|c|c|c|}
\hline 9 & $\begin{array}{l}\text { Abdollahi } \\
\text { M., et al. }\end{array}$ & $\begin{array}{l}\text { A review of drug- } \\
\text { induced oral } \\
\text { reactions }\end{array}$ & 2003 & $\begin{array}{l}\text { J. Contemp. Dental } \\
\text { Pract. }\end{array}$ & Review & 119 & 4.96 \\
\hline 10 & $\begin{array}{l}\text { Asconapé } \\
\text { J.J. }\end{array}$ & $\begin{array}{l}\text { Some common } \\
\text { issues in the use } \\
\text { of antiepileptic } \\
\text { drugs }\end{array}$ & 2002 & Semin. Neurol. & Review & 119 & 4.96 \\
\hline 11 & $\begin{array}{l}\text { Trackman } \\
\text { P.C., et al. }\end{array}$ & $\begin{array}{l}\text { Connective tissue } \\
\text { metabolism and } \\
\text { gingival } \\
\text { overgrowth }\end{array}$ & 2004 & $\begin{array}{l}\text { Crit. Rev. Oral Biol. } \\
\text { Med. }\end{array}$ & Review & 111 & 4.625 \\
\hline 12 & - & $\begin{array}{l}\text { Informational } \\
\text { paper: Drug- } \\
\text { associated } \\
\text { gingival } \\
\text { enlargement }\end{array}$ & 2004 & J. Periodontol. & Review & 104 & 4.63 \\
\hline 13 & $\begin{array}{l}\text { Nishikawa } \\
\text { S. et al. }\end{array}$ & $\begin{array}{l}\text { Pathogenesis of } \\
\text { Drug-Induced } \\
\text { Gingival } \\
\text { Overgrowth. A } \\
\text { Review of Studies } \\
\text { in the Rat Model }\end{array}$ & 1996 & J. Periodontol. & Review & 103 & 4.29 \\
\hline 14 & $\begin{array}{l}\text { Tipton D.A., } \\
\text { et al. }\end{array}$ & $\begin{array}{l}\text { Fibroblast } \\
\text { heterogeneity in } \\
\text { collagenolytic } \\
\text { response to } \\
\text { cyclosporine }\end{array}$ & 1991 & J. Cell. Biochem. & Article & 93 & 3.88 \\
\hline 15 & $\begin{array}{l}\text { Butler R.T., } \\
\text { et al. }\end{array}$ & $\begin{array}{l}\text { Drug-induced } \\
\text { gingival } \\
\text { hyperplasia: } \\
\text { phenytoin, } \\
\text { cyclosporine, and } \\
\text { nifedipine. }\end{array}$ & 1997 & J. Am. Dent. Assoc. & Article & 93 & 3.88 \\
\hline 16 & $\begin{array}{l}\text { Brown R.S., } \\
\text { et al. }\end{array}$ & $\begin{array}{l}\text { On the mechanism } \\
\text { of drug-induced } \\
\text { gingival } \\
\text { hyperplasia }\end{array}$ & 1991 & J. Oral Pathol. Med. & Review & 89 & 3.71 \\
\hline 17 & $\begin{array}{l}\text { Schincaglia } \\
\text { G.P. et al. }\end{array}$ & $\begin{array}{l}\text { Cyclosporin-A } \\
\text { increases type I } \\
\text { procollagen } \\
\text { production and } \\
\text { mRNA level in } \\
\text { human gingival } \\
\text { fibroblasts in vitro }\end{array}$ & 1992 & J. Oral Pathol. Med. & Article & 87 & 3.63 \\
\hline 18 & $\begin{array}{l}\text { lacopino } \\
\text { A.M., et al. }\end{array}$ & $\begin{array}{l}\text { Phenytoin and } \\
\text { Cyclosporine A } \\
\text { Specifically } \\
\text { Regulate } \\
\text { Macrophage } \\
\text { Phenotype and } \\
\text { Expression of } \\
\text { Platelet-Derived } \\
\text { Growth Factor and } \\
\text { Interleukin-1 in } \\
\text { Vitro and in Vivo: } \\
\text { Possible Molecular } \\
\text { Mechanism of } \\
\text { Drug-Induced }\end{array}$ & 1997 & J. Periodontol. & Article & 85 & 3.54 \\
\hline
\end{tabular}


Gingival

Hyperplasia

\begin{tabular}{|c|c|c|c|c|c|c|c|}
\hline 19 & $\begin{array}{l}\text { Seymour } \\
\text { R.A., et al. }\end{array}$ & $\begin{array}{l}\text { Drugs and the } \\
\text { periodontium }\end{array}$ & 1988 & J. Clin. Periodontol. & Review & 80 & 3.33 \\
\hline 20 & $\begin{array}{l}\text { Marshall } \\
\text { R.l., et al. }\end{array}$ & $\begin{array}{l}\text { A clinical review of } \\
\text { drug-induced } \\
\text { gingival } \\
\text { overgrowths }\end{array}$ & 1999 & Aust. Dent. J. & Review & 78 & 3.25 \\
\hline
\end{tabular}

\section{Figures}

\section{Figure 1}

Citation characteristics of the papers on DIGO. a The frequency of paper types. $\mathbf{b}$ The number of citations and that after removal of self-citations of papers by year of publication. $\mathbf{c}$ The number of papers included by year of publication

\section{Figure 2}

Research trend and hotspots of DIGO. a The frequency of drug related to DIGO. b The frequency of study design. c Top20 keywords

\section{Figure 3}

The information on the (a) author (rank 1-6), (b) institution (rank 1-15), (c) country or region of origin (rank 1-15) and (d) journal of publication (rank 1-10) with the largest number and (e) journal with high IF (rank 1-20)
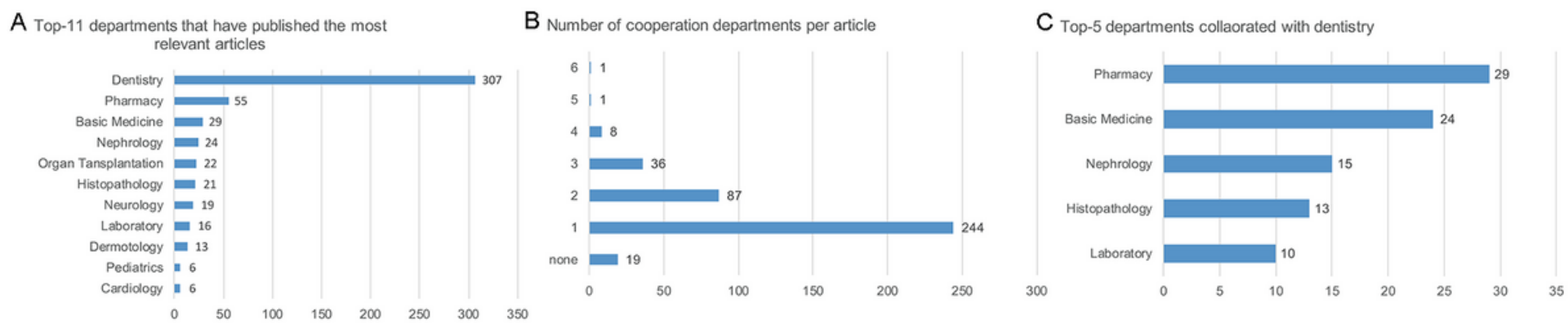

\section{Figure 4}

Collaborative studies of DIGO. a Top-11 departments that have published the most relevant articles $\mathbf{b}$ Number of cooperation departments per article c Top-5 departments collaborated with dentistry

*none: No source of department information 